EGU2020-8231

https://doi.org/10.5194/egusphere-egu2020-8231

EGU General Assembly 2020

(c) Author(s) 2020. This work is distributed under

the Creative Commons Attribution 4.0 License.

\title{
Multi-decadal (1953 - 2017) response of rock glacier morphodynamics to climate change in the Kauner Valley in the Ötztaler Alps, Austria based on historical aerial images and airborne LiDAR data
}

Fabian Fleischer, Florian Haas, Tobias Heckmann, Moritz Altmann, Livia Piermattei, Jakob Rom, and Michael Becht

Catholic University of Eichstätt-Ingolstadt, Physical Geography, Eichstätt, Germany (fabian.fleischer@ku.de)

Although the observed global climate change has particularly affected high-alpine regions and these geosystems seem to react very sensitively to changes in external forcing, there is a lack of understanding about the effect of a changing climate upon high-alpine landscapes at the timescale of decades. In the case of rock glaciers, which are common features in high alpine periglacial landscapes, numerous studies suggest a general acceleration of rock glacier displacement rates accompanied by surface lowering. This behaviour has been attributed to the rising permafrost temperature, induced by atmospheric warming and regulated by thermo-hydrological processes. On the other hand, decoupled kinematics of nearby rock glaciers under the same climatic forcing have also been proven. This is attributed to different local topo-climatic conditions and genesis of the investigated rock glaciers. To contribute to the understanding of multi-decadal rock glacier response to climate change, we investigate the morphodynamic changes for selected rock glaciers in the Upper Kauner Valley in the Ötztaler Alps, Austria, a catchment comprising numerous rock glaciers of different size, genesis, elevation, aspect and activity status. This is done for multiple time slices between 1953 and 2017. These changes are analysed with respect to rock glacier characteristics and changes in the meteorological forcing. This work is part of the interdisciplinary and multi-university research project SEHAG (Sensitivity of high alpine geosystems to climate change since 1850), which aims to investigate changes in different processes of alpine geosystems and their interaction.

In order to investigate morphodynamics of the rock glaciers, we use digital photogrammetry to generate orthophotos and digital elevation models from historical aerial images (available since 1953). Additionally, we use digital elevation models generated from three airborne LiDAR surveys within the period 2006-2017. While the diachronic analysis of digital elevation models predominantly addresses vertical surface changes, image correlation of multitemporal digital orthophotos yields information on rates of horizontal displacement. The results for the individual rock glaciers are compared to each other and to meteorological data of nearby weather stations to analyse the response of rock glaciers with different characteristics to changing climate forcing. 
